\title{
A Large Parotid Hemangioma Managed Successfully with Propranolol
}

\author{
Fandresena Arilala Sendrasoa (D), Tsiory larintsoa Razafimaharo, Samson Leophonte Ramily, \\ Lala Soavina Ramarozatovo, Fahafahantsoa Rapelanoro Rabenja \\ Department of Dermatology, Faculty of Medicine, University of Antananarivo, Antananarivo, I0I, Madagascar
}

Correspondence: Fandresena Arilala Sendrasoa, Department of Dermatology, Faculty of Medicine, University of Antananarivo, Antananarivo, I0I, Madagascar, Email nasendrefa@yahoo.fr

\begin{abstract}
The treatment of parotid hemangiomas has posed a challenge. A male infant presented with large hemangioma of the right parotid gland diagnosed at the age of 3 months. Starting at the age of 4 months, he was treated with oral propranolol for 10 months, which led to a marked reduction in tumor size and strawberry hemangioma. Our case shows that propranolol is effective and safe in treating large parotid infantile hemangioma.
\end{abstract}

Keywords: large parotid hemangioma, propranolol, infantile

\section{Introduction}

Parotid hemangiomas represent $0.4-0.6 \%$ of the tumors involving the parotid gland, and are more common in children than in adults. ${ }^{1}$ Most of them are asymptomatic. Previous studies have shown that propranolol shrinks most parotid hemangiomas. ${ }^{2}$ However, $2-20 \%$ of patients with infantile hemangioma may present resistance to propranolol or have contraindications. $^{3}$

We present a male infant with a large hemangioma of the right parotid gland managed successfully with propranolol.

\section{Case Report}

A 3-month-old male, otherwise healthy, presented with a swelling over the right side of his face that was initially noticed at 4 weeks of age. It was rapidly increasing in size. There was no pain, history of trauma, prematurity, or advanced maternal age. Clinical examination revealed a large swelling in the right parotid region which was extending behind the ipsilateral ear lobe. Strawberry hemangioma was noted in the overlying cutaneous tissue. The mass was soft and non-tender (Figure 1A and B). An ultrasound scan showed a large mass in the right parotid gland, which measured $7.1 \times 6.1 \times 6.8 \mathrm{~cm}$. The mass was very vascular with low-resistance arterial and venous components, mainly from the branch of the right carotid artery, and drained into the right jugular vein. Based on the clinical presentation and sonographic parameters, the diagnosis of infantile hemangioma of the right parotid gland was made. Cervical MRI showed a T1-isointense (Figure 2A), T2-hyperintense lesion replacing the whole of the parotid gland (Figure 2B), which was pushing against the digestive tract. Oral propranolol was initiated at $1 \mathrm{mg} /$ $\mathrm{kg} /$ day as a single oral dose, after pretreatment evaluation, at the age of 4 months. It was well tolerated by our patient: monitoring of heart rate, respiratory rate, and blood pressure was normal. His propranolol dose was increased to $2 \mathrm{mg} / \mathrm{kg} / \mathrm{day}$ and weight adjusted at monthly visits without side effects. For the first month, the infant was followed up on a 2-weekly, then at a monthly interval. Significant shrinkage and paleness of the lesion was noted at 4 months. At the 10-month follow-up, there was complete disappearance of the parotid hemangioma (Figure $3 \mathrm{~A}$ and $\mathrm{B}$ ). 

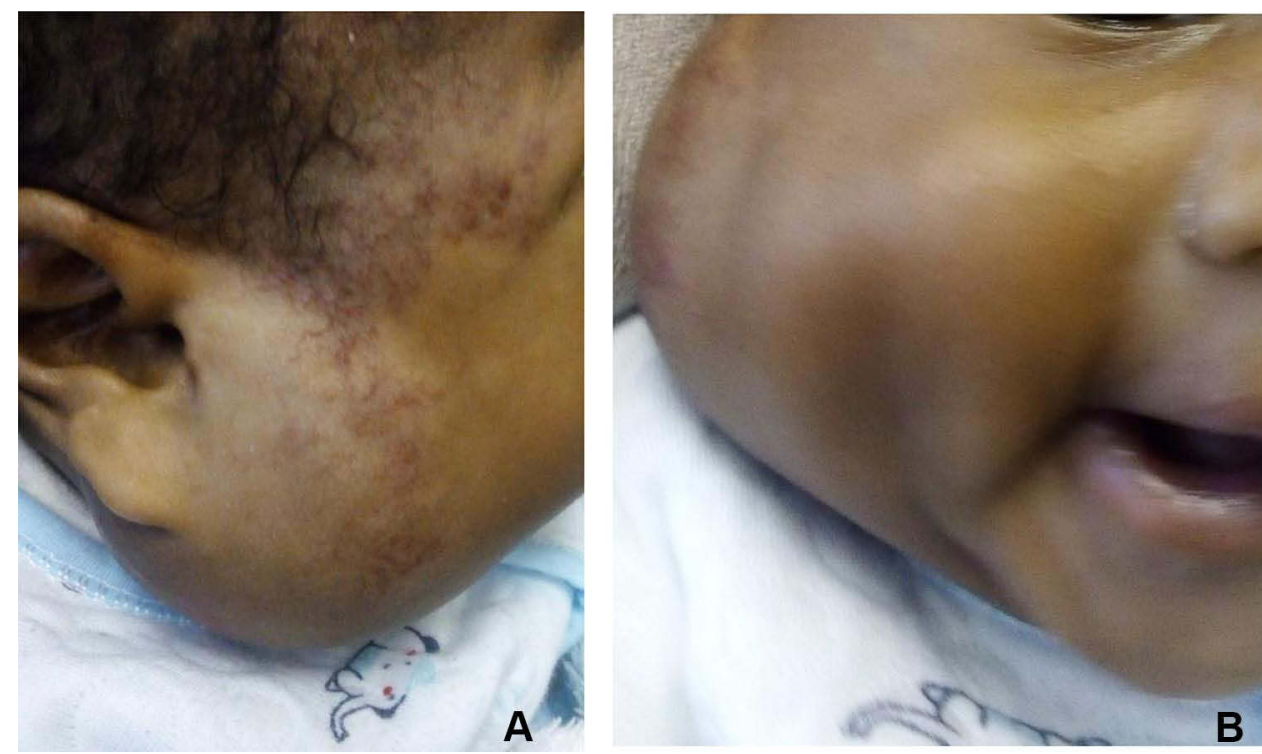

Figure I Large swelling in the anatomic area of the right parotid gland, prior to initiating treatment: (A) right profile; (B) front view.
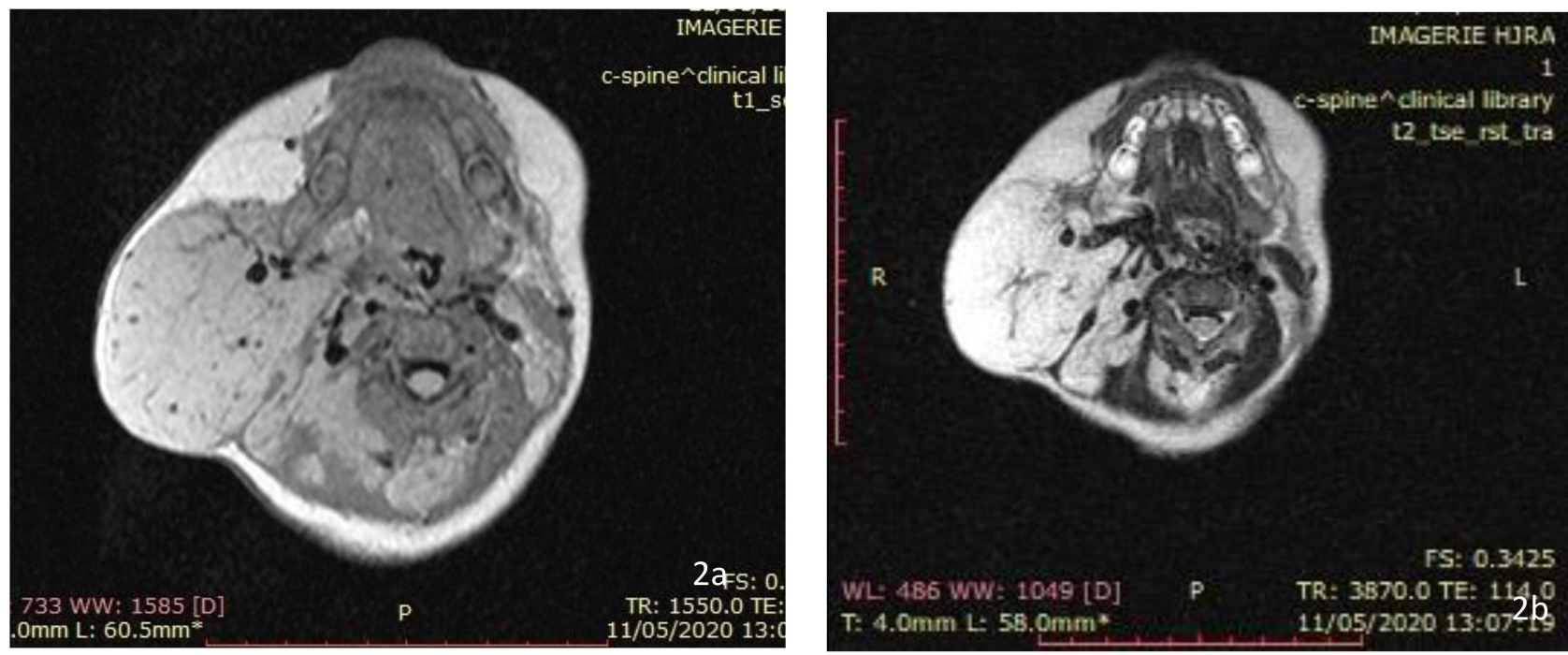

Figure 2 Magnetic resonance imaging showing (A) TI-isointense and (B) T2-hyperintense lesion replacing the whole of the parotid gland.

\section{Discussion}

Hemangioma of the parotid gland is the most common tumor of the salivary glands in childhood; however, it represents only $1-5 \%$ of all salivary gland tumors. ${ }^{4}$

Most hemangiomas of the parotid gland can be diagnosed based on the typical clinical presentation of a mass that is evident after birth and shows rapid growth. As in our case, the diagnosis may be made clinically if the skin overlying the lesion is involved. MRI gives more precision on the size and depth of the tumor and its relationship to adjacent structures. ${ }^{5}$

The treatment of pediatric infantile hemangioma of the head and neck, and particularly of the parotid gland, is not codified. The size, stage, and location of lesions, presence of ulceration and bleeding, functional obstruction, and risk of deformity are the determinants of the treatment plan. The impressive effect of propranolol in treating infantile 

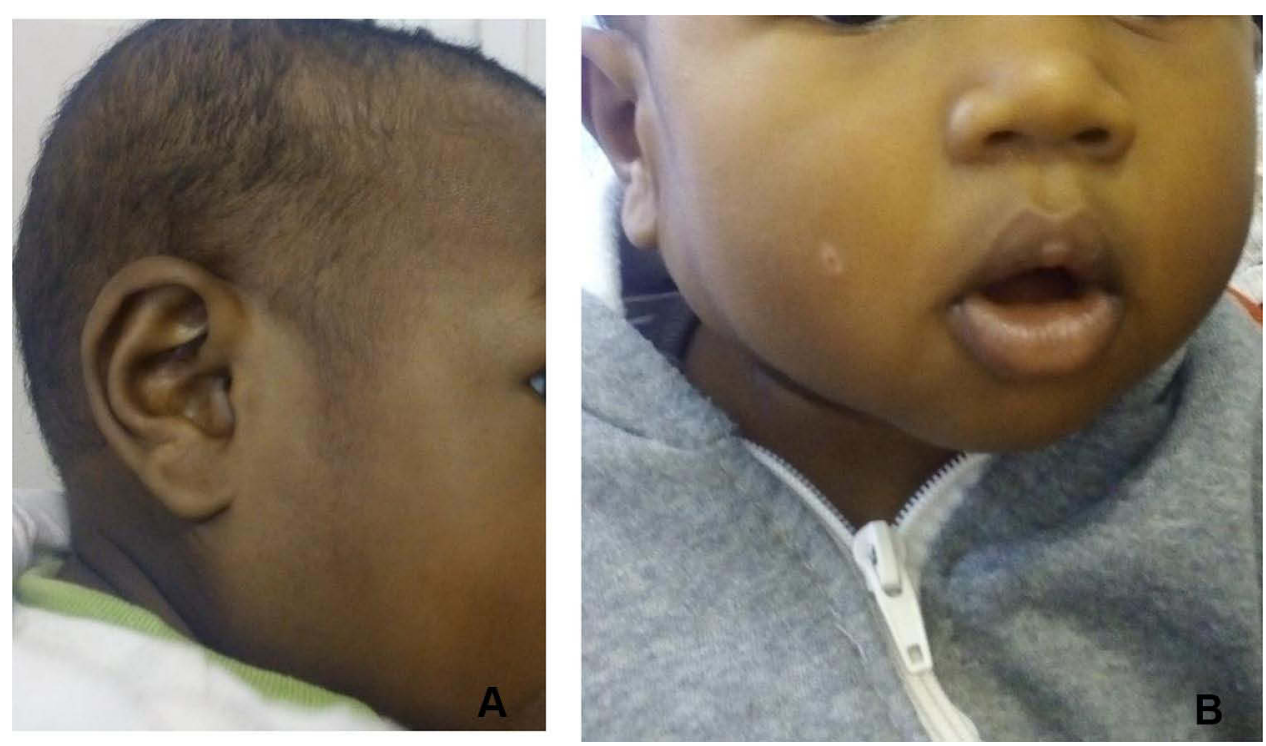

Figure 3 Marked reduction of parotid hemangioma after 10 months of oral propranolol: (A) right profile; (B) front view.

hemangiomas changed the principle in their treatment, with several reports being published since $2008 .{ }^{6}$ In addition, propranolol is well tolerated.

Several authors have reported the effectiveness of propranolol in hemangioma of the parotid gland. ${ }^{7,8}$ However, Harris and Phillips found that parotid hemangiomas have a lower response rate to propranolol and need a longer treatment course compared to infantile hemangioma at other sites. ${ }^{9}$

Most infantile hemangiomas complete their proliferative growth phase before 9 months of age. However, some authors have reported a recurrence of hemangioma of the parotid gland when propranolol was discontinued after 9 months of age. ${ }^{9,10}$ This is why we decided to continue propranolol therapy until 14 months of age. As described in our case, large size and facial location are the most important predictors of poor short-term outcomes.

Our patient's case shows that propranolol is effective and safe in treating infantile hemangioma of the parotid gland.

\section{Abbreviation}

MRI, magnetic resonance imaging.

\section{Ethical Approval and Consent for Publication}

Informed consent was obtained from both parents of the patient. The publication of this case has been approved by the University Hospital Joseph Raseta Befelatanana Antananarivo Ethics Committee.

\section{Author Contributions}

All authors made substantial contributions to conception and design, acquisition of data, or analysis and interpretation of data; took part in drafting the article or revising it critically for important intellectual content; agreed to submit to the current journal; gave final approval of the version to be published; and agree to be accountable for all aspects of the work.

\section{Funding}

There is no funding to report.

\section{Disclosure}

The authors report no conflicts of interest for this work. 


\section{References}

1. Lara-Sanchez H, Peral-Cagigal B, Madrigal-Rubiales B, Verrier-Hernandez A. Cavernous hemangioma of the parotid gland in adults. $J$ Clin Exp Dent. 2014;6(5):e592-e594. doi:10.4317/jced.51750

2. Sinno H, Thibaudeau S, Coughlin R, Chitte S, Williams B. Management of infantile parotid gland hemangiomas: a 40-year experience. Plast Reconstr Surg. 2010;125:265-73.m. doi:10.1097/PRS.0b013e3181c2a55a

3. Phillips RJ, Lokmic Z, Crock CM, Penington A. Infantile haemangiomas that failed treatment with propranolol: clinical and histopathological features. J Paediatr Child Health. 2014;50:619-625. doi:10.1111/jpc.12600

4. Som PM, Curtin HD. Head and Neck Imaging. Mosby; 2003.

5. George CD, Hall-Craggs MA, Jones BM. Parotid haemangioma in infants: MR imaging at 1.5T. Pediatr Radiol. 1991;21:483-485. doi:10.1007/ BF02011717

6. Léauté-Labrèze C, Dumas de la Roque E, Hubiche T, Boralevi F, Thambo JB, Taïeb A. Propranolol for severe hemangiomas of infancy. $N$ Engl $J$ Med. 2008;358(24):2649-2651. doi:10.1056/NEJMc0708819

7. Li G. Oral propranolol for parotid infantile hemangiomas. J Craniofac Surg. 2015;26:438-440.

8. Chang L, Jin Y, Lv D. Use of propranolol for parotid hemangioma. Head Neck. 2016;38(S1):E1730-6. doi:10.1002/hed.24308

9. Harris J, Phillips JD. Evaluating the clinical outcomes of parotid hemangiomas in the pediatric patient population. Ear Nose Throat J. 2019;100: NP242-NP245. doi:10.1177/0145561319877760

10. Mantadakis E, Tsouvala E, Deftereos S, Danielides V, Chatzimichael A. Involution of a large parotid hemangioma with oral propranolol: an illustrative report and review of the literature. Case Rep Pediatr. 2012;2012:1-5. doi:10.1155/2012/353812

\section{Publish your work in this journal}

Clinical, Cosmetic and Investigational Dermatology is an international, peer-reviewed, open access, online journal that focuses on the latest clinical and experimental research in all aspects of skin disease and cosmetic interventions. This journal is indexed on CAS. The manuscript management system is completely online and includes a very quick and fair peer-review system, which is all easy to use. Visit http://www. dovepress.com/testimonials.php to read real quotes from published authors.

Submit your manuscript here: https://www.dovepress.com/clinical-cosmetic-and-investigational-dermatology-journal 